UDC: $378: 37.011 .31+159.955 .4$

DOI: https://doi.org/10.24195/2414-4665-2017-5-21

\author{
Natalia Senchyna, \\ educator, Scientific Methodical Center for \\ Foreign Language Teachers' Post-Graduate Studies, \\ Odessa Regional Advanced Training Institute for Teachers,
}

8, Nakhimova lane, Odessa, Ukraine,

post-graduate student, Department of Theory and Methods of Preschool Education, South Ukrainian National Pedagogical University named after K. D. Ushynsky,

26, Staroportofrankivska Str., Odessa, Ukraine

\title{
PECULIARITIES OF THE DEVELOPMENT OF HUMANITIES TEACHERS' PEDAGOGICAL REFLECTION
}

The article deals with the approaches to the determination of the essence of reflection in general, as well as the peculiarities of pedagogical reflection in particular. The prerequisite of humanities teacher's professional development is his/her ability for reflection which involves self-cognition, self-analysis and activity self-assessment, as well as understanding the way he/she is perceived by others as a personality. The post-graduate pedagogical education is of particular importance in the development teachers' reflection. Pedagogical reflection is considered as a teacher's ability for self-observation, self-cognition, self-assessment, as well as the ability to compare one's own opinion and other people ones about oneself, to assess one's own achievements critically, to determine ways of professional and personal development. As a result of the carried out survey of humanities teachers taking post-graduate course it has been proved that they are faced with the problem of using pedagogical reflection in their work, though they are quite aware of its importance. According to the obtained data there is a necessity of developing pedagogical reflection skills in the teachers who have little experience of working at educational institutions. Their characteristic feature is that they are afraid of making mistakes because of the ones made in the past. The use of business games, role-playing, exercises and games focused on the analysis of different educational situations will contribute to the development of teachers' reflexive skills. The further research studies are planned to involve the design of the methods to develop the humanities teachers' pedagogical reflection in terms of post-graduate education.

Keywords: reflection, pedagogical reflection, humanities, humanities teachers, post-graduate education.

\section{Introduction}

The modernization of the modern school education puts forward the demands to teachers' work, which determines the necessity of their constant professional development, self-perfection for creative self-fulfillment in their profession. Reflection is considered to be the prerequisite of humanities teachers' professional development, which involves self-cognition, self-analysis and self-assessment. It is associated with the fact that a modern teacher has to be able to use inner resources when dealing with his/her colleagues, students and their parents, especially in problematic situations when searching for the ways to solve them.

According to some scientists (O. Bondarchuk, V. Maslov, V. Oliinyk, Ye. Chernyshova) the system of post-graduate pedagogical education plays a unique role in the development of teachers' reflection, as it is aimed at their professional development [11]. In the system of post-graduate pedagogical education, the maintaining of teachers' qualification, as well as the development of their professional qualities, including pedagogical reflection, has a strong impact on the improvement of the quality of schooling, forming spiritually rich school students' personalities.

It should be noted that the issue of pedagogical reflection in not new in the modern psycho-pedagogical science. Its certain aspects have been studied by M. Alekseiev, K. Verbova, I. Zymnia, A. Ksrpov, B. Kovaliov, S. Kondratieva and others. These scientists emphasize the necessity of teachers' reflexive skills formation, as well as their development in the process of teaching, because the comprehension of prerequisites, regularities and mechanisms of one's own life and professional experience, selfanalysis and assessment of one's own actions and deeds, self-cognition and self-predicting contribute to the formation of an individual path, professional style and are considered as a source of self-development [9].

The paper aims to consider the peculiarities of humanities teachers' pedagogical reflection in terms of school education modernization.

\section{Discussion}

In scientific literature on the issue, the term "reflection" is interpreted as a form of "theoretical" activity of a "socially developed" person, which is aimed at comprehension of all his/her acts and laws; as the activity focused on self-cognition which reveals the specificity of human spiritual work, as comprehension of something by means of learning and comparing $[17$, p. 579]. It is not just the understanding by a person of herself/himself, but also finding out what others think about him/her, his/her personal traits, features, emotional reactions and cognitive ideas $[14$, p. 631]. It is also regarded as a process of dual 
mutual "mirroring" of each other, the essence of which is presentation of each other's peculiarities [12, p. 609].

According to O. Myroshnyk, the concept of reflection in its narrow sense is used to determine the acts of self-consciousness, self-cognition, self-analysis, the presence of mechanisms and norms of conscious control over the process of development and functioning of one's knowledge. Reflection is one of the mechanisms of selfdetermination and the condition of existence in "cause sui" status [8, p. 164].

D. Levites considers reflection as the person's understanding of his/her own emotional reactions, states, thoughts, and experiences. He believes that with the help of reflection the correlation between person's consciousness, values, thoughts and other people's, society's ones is achieved. The most important function of reflection is its ability to manage one's activity according to one's own values, form and turn to the new mechanisms due to the changes in the conditions, aims and tasks of activity [5, p. 14].

In the works of M. Mirimanova, reflection is considered as a mechanism of the development of selforganizing systems. It is a way to look at oneself from the outside, and the models of such a "look" can be diverse: one can focus one's imagined look on oneself and try to observe oneself as a certain object. Reflection can be a way of understanding oneself through the others (social reflection). Trying to comprehend another person through his/her attitude towards us, through his/her deeds and behavior, we design his/her way of seeing us in our consciousness. Every new model in a certain sense is the "mirror" in which we can see our "reflection", get information about oneself and one's own relations with the world in a form of the models reflected in our consciousness [7].

Thus, in its conceptual meaning, reflection is a form of praxis of certain contents of individual consciousness, activity, communication, and in a general sense it is human ability for self-analysis, understanding and reinterpretation of one's social relations with the environment and is a component of the developed intelligence [4].

V. Lukashevych distinguished the following three forms of reflection: 1) primary reflection, aimed at the analysis of everyday deeds and knowledge associated with them, which helps to specify its essence and frames; 2) philosophic reflection as the comprehension of ultimate grounds of being and thinking, human culture in general as a way of the society's existence; 3 ) theoretical reflection as a critical analysis of prerequisites, forms, methods and results of human activity in any sphere which is based on the principles of consistency, determinism, logical sequence and adopted in science [6, p. 51].

Teacher's ability for pedagogical reflection is significant in his/her work as it helps to create the individual professional style, to achieve the adequate self-esteem of his/her professional skills, analyze and predict results of work; also it encourages self-development. This phenomenon is interpreted in the following ways:
- as a process of self-identification of the educational interaction subject with an educational situation and its "components": students, teacher, conditions of the educational process participants' development, environment, teaching technologies (N. Suvorova) [15];

- as teacher's attitude towards himself/herself as a subject of work, prediction of his/her acts in an educational situation; the ability to compare his/her vision of himself/herself with the opinions of the interaction participants, which helps a teacher to understand in what way he/she is perceived and assessed by other people (I. Kara) [3];

- teacher's recognition of himself/herself as a subject of activity: his/her peculiarities, abilities, the attitude of students, parents, colleagues, administration towards him/her; understanding aims and structure of activity, means of its optimization (R. Tur), [16];

- as a teacher's ability to assess his/her behavior and deeds, understand the way children and colleagues conceive him/her; in a general sense it is considered as thinking, self-observation, ability to see and reconsider oneself and one's own work (Z. Ostasiuk), [10].

as an integral personality trait manifested in reflexive behavior based on reflexive knowledge, attitude towards reflexive skills and activity. Professional reflection develops when a teacher finds a new sense of his/her activity through comprehension of his/her position in a problematic situation (H. Yermakova), [2];

- as a teacher's ability for the analysis, comprehension and building of the value basis for his/her work, grounded on self-imaging as a subject of activity, personality in the system of social relations, which is manifested in the analysis of the grounds of his/her social relations with students, his/her professional development (A. Biziaieva), [1].

Emphasizing the significance of reflection in future teachers' professional self-fulfillment L. Rybalko summarizes the essence of this phenomenon as follows: it is an ability to think (understanding the necessity and the results of professional self-fulfillment); it is a conscious process having positive impact on the understanding of the necessity of full self-fulfillment in the process of studying; it is self-observation (as a method of professional self-fulfillment); it is an ability to refer to one's own "self", analyze the knowledge about it, which accelerates the process of professional self-fulfillment; it is a self-creating process as it creates new knowledge about one's own abilities in professional self-fulfillment [12, p. 265-266].

Based on the abovementioned, we consider pedagogical reflection as a teacher's ability for self-observation, self-cognition, self-analysis, the ability to compare other people's opinion about oneself with one's own one, to assess one's own professional achievements critically, as well as to determine the ways of professional development.

\section{Discussion}

In order to find out the level of teachers' awareness 
of the essence of pedagogical reflection we have conducted a research involving 56 humanities teachers taking post-graduate education in Odessa Institute for Postgraduate Studies, who have filled in the questionnaire developed by us.

According to the research outcomes, most of the surveyed consider reflection as "the analysis of one's own activity", "the ability to look at oneself from the outside".

Most of the respondents work on the formation of their students' reflexive skills. At this, they admit that the specificity of their work involves the development of analytical skills of school students. It is associated with the fact that in the process of reading literary works with students, the teacher's task is to teach them to analyze them, trying to understand what the author wanted to tell us, analyze the characters' deeds, and to form their own opinions about the events described in the work. Besides, the surveyed emphasized that being homeroom teachers, they faced the necessity to solve different problems arising in school environment, helping and encouraging their students to dwell upon their deeds and their consequences.

The teachers were met with some difficulties when trying to answer the question about the essence of pedagogical reflection and its difference from reflection in general. Most of them admitted that it is "the analysis of one's own work" (which corresponds to their answers to the first question), though their could not explain the difference. Some of the teachers noted that pedagogical reflection provides the ability for self-cognition, realization of the mistakes made in the process of interacting with students, which caused a conflict situation with them or their relatives; the ability to solve it, make respective conclusions to avoid the similar mistakes in the future.

Besides, according to the respondents' answers, they perform pedagogical reflection in the process of analyzing the lesson or event conducted, or if students do not understand the new learning material. Only a few of them noted that they try to analyze themselves in every situation, to "put themselves in their students' shoes", understand how to increase students' interest in the subject, etc.

To sum up, it is worth noting that in general the respondents are quite aware of the essence of pedagogical reflection, though they do not always apply it in their work which indicates that there is a problem of the development of humanities teachers' pedagogical reflection. It means that it is necessary to find the ways to contribute to its development in terms of post-graduate education.

In order to assess the level of humanities teachers' skills of analyzing, generalizing and estimating their own work, the ability to assess their capabilities, make respective conclusions leading to self-development, we used the Method of Ontogenetic Reflection by N. Fetiskin.

\section{ЛІТЕРАТУРА}

1. Бизяева А. А. Рефлексивные процессы в сознании и деятельности учителя : дисс... канд. психол.
The research outcomes have shown that $20.1 \%$ of the respondents have the low level of reflexive skills (this group predominantly involved the "beginners", i.e. the teachers who have little teaching experience). Their characteristic feature is that they are afraid of making mistakes because of the ones made in the past. These teachers are very careful, though it is not a guarantee of their success. Their critical way of thinking prevents them to do what they really want to, they have no reflection of the experience. They tend to complicate everything in their lives. The decisions made by them satisfy neither themselves, nor other people. In every situation, they need recommendations and help of more experienced teachers. These qualities indicate their undeveloped level of pedagogical reflection.

The satisfactory level of pedagogical reflection was found in $47.4 \%$ of the respondents. These teachers have the skills of analyzing their mistakes, but sometimes they do not make the respective conclusions, and as a result, they make the same mistakes again and again. They have the skills of planning their work, through cannot correct it in a proper way. In order to solve this problem it is necessary to find the ways to develop pedagogical reflection of humanities teachers in the system of post-graduate education.

$32.5 \%$ of the teachers have the high level of pedagogical reflection. It is worth noting that these are the pedagogues having great experience in teaching, they are characterized with the ability to analyze and assess their experience and make right conclusions. They can be called the creators of their life journeys as they have the skills of planning their future.

\section{Conclusions}

The results obtained show the necessity of dealing with the challenge of the development of humanities teachers' pedagogical reflection skills in the system of post-graduate education. In our opinion, the use of different business games, role-playing, exercises and games focused on the analysis of educational situations will contribute to the development of teachers' reflexive skills.

Summing up, it should be noted that pedagogical reflection is a significant source of teachers' selfdevelopment, considering the fact that it results in the reassessment of the level of their pedagogical mastery, realization and understanding of educational problems, their analysis and ways to solve them, determination of the ways of their professional development.

Taking into account that the humanities teachers are faced with the problem of the lack of pedagogical reflection skills, our further research studies are planned to involve the design of the methods to develop the pedagogical reflection in terms of post-graduate education.

наук : 19.00.07 / Анна Александровна Бизяева. - Санкт-Петербург, 1993. - 238 с. 
2. Ермакова Г. Г. Педагогические условия развития профессиональной рефлексии педагога : дис. канд пед. наук : 13.00.01 / Галина Григорьевна Ермакова. - Оренбург, 1999. - 153 с.

3. Кара С. І. Самосвідомість як підгрунтя рефлексивності та важливий показник професіоналізму майбутніх учителів фізичного виховання / С. І. Кара // Наука і освіта. - Одеса, 2014. - № 4. - С. 75-78.

4. Ковальчук I. М. Розвиток професійних якостей учителів технологій у післядипломній педагогічній освіті : дис... канд. пед. наук : 13.00.04 / Ірина Михайлівна Ковальчук. - К., 2016. - 350 с.

5. Левитес Д. «Хорошо ли мы работаем, когда думаем, что работаем хорошо?» / Д. Левитас. - М. : ЛОР, 2005. - С. 11-23.

6. Лукашевич В. К. Философия и методология науки / В.К. Лукашевич. - Минск : Современная школа, 2006. - 320 с.

7. Мириманова М. С. Рефлексия как механизм развития самоорганизующихся систем / М. С. Мириманова // Развитие личности. 2001. - № 1. - C. $49-65$.

8. Мирошник О. Г. Професійно-педагогічна рефлексія у вимірах основних сфер професійної активності вчителя / О. Г. Мирошник // Психологія і особистість. - 2015. - № 1 (7). - С. 162-175.

9. Освіта дорослих : енциклопедичний словник / за ред. В. Г. Кременя, Ю. В. Ковбасюка; [упоряд.: Н. Г. Протасова, Ю. О. Молчанова, Т. В.Куренна; ред. рада: В. Г. Кремень,

\section{REFERENCES}

1. Biziaeva, A. A. (1993). Refleksivnye protsessy v soznanii i deiatelnosti uchitelia [Reflexive processes in teacher's consciousness and activities]. Candidate's thesis. Saint Petersburg [in Russian].

2. Yermakova, G. G. (1999). Pedagogicheskie usloviia razvitiia professionalnoi refleksii pedagoga [Pedagogical conditions of the development of teacher's professional reflection]. Candidate's thesis. Orenburg [in Russian].

3. Kara, S. I. (2014). Samosvidomist yak pidhruntia refleksyvnosti ta vazhlyvyi pokaznyk profesionalizmu maibutnikh uchyteliv fizychnoho vykhovannia [Selfconsciousness as a basis for reflexivity and significant indicator of future physical education teachers' professionalism]. Nauka i osvita - Science and education, 4, 7578. Odesa [in Ukrainian].

4. Kovalchuk, I. M. (2016). Rozvytok profesiinykh yakostei uchyteliv tekhnolohii u pisliadyplomnii pedahohichnii osviti [Development of professional qualities of technologies teachers in post-graduate pedagogical education]. Candidate's thesis. Kyiv [in Ukrainian].

5. Levites, D. (2005). Khorosho li my rabotaem, kogda dumaem, chto rabotaem khorosho? [Are we working well when we think that do it well?]. (pp. 11-23). Moscow: LOR [in Russian].

6. Lukashevich, V. K. (2006). Filosofiia i metod-
Ю. В. Ковбасюк, Н. Г. Протасова та ін.]. - К. : Основа, 2014. $-496 \mathrm{c}$.

10. Остасюк 3. А. Умови формування педагогічної самоефективності майбутніх учителів музики / 3. А. Остасюк // Збірник науково-методичних праць викладачів Луцького педагогічного коледжу. - № 4. Луцьк : Луцький педагогічний коледж, 2011. - С. 72-80.

11. Палько Т. В. Психологічні особливості розвитку рефлексії вчителів в умовах післядипломної педагогічної освіти : автореф. дис.. на здобуття наук. ступеня канд. психол. наук : спец. 19.00.07 «Педагогічна та вікова психологія» / Т. В. Палько. - К., 2015. - 20 с.

12. Психология. Словарь / Под ред. А. В. Петровского и М. Г. Ярошевского. - М. : ИПЛ, 1990. - 702 c.

13. Рибалко Л. С. Акмеологічні засади професійно-педагогічної самореалізації майбутнього вчителя : дис... докт. пед. наук : 13.00.04 / Людмила Сергіївна Рибалко. - Харків, 2008. - 457 с.

14. Словарь практического психолога / сост. С. Ю. Головин. - Минск : Харвест, 1998. - 800 с.

15. Суворова Н. Г. Интерактивное обучение : новые подходы / Н. Г. Суворова // Учитель. - 2000. № 1. - С. 25-27.

16. Тур Р. Й. Педагогічна рефлексія - основа формування творчого саморозвитку особистості / Р. Й. Тур // Управління школою. - Харків, 2004. - № 13. - C. 22-24.

17. Философский энциклопедический словарь / [под ред. Л. Ф. Ильичева и др.]. - М. : Сов. Энциклопедия, 1983. -840 с.

ologiia nauki [Philosophy and methods of science]. Minsk: Sovremennaia shkola [in Russian].

7. Mirimanova, M. S. (2001). Refleksiia kak mekhanizm razvitiia samoorganizuiushchikhsia sistem [Reflection as a mechanism of self-organizing systems' development]. Razvitie lichnosti-Personal development, 1, 49-65 [in Russian].

8. Myroshnyk, O. H. (2015). Profesiinopedahohichna refleksiia u vymirakh osnovnykh sfer profesiinoi aktyvnosti vchytelia [Professional pedagogical reflection in terms of basic spheres of teacher's professional activity]. Psykholohiia $i$ osobystist - Psychology and personality, 1 (7), 162-175 [in Ukrainian].

9. Kremen, V. H., Kovbasiuk, Yu. V. (Ed.). (2014). Osvita doroslykh : entsyklopedychnyi slovnyk [Adult education: encyclopedic dictionary]. Kyiv: Osnova [in Ukrainian].

10. Ostasiuk, Z. A. (2011). Umovy formuvannia pedahohichnoi samoefektyvnosti maibutnikh uchyteliv muzyky [Conditions of future Music teachers' pedagogical self-efficiency development]. Zbirnyk naukovometodychnykh prats vykladachiv Lutskoho pedahohichnoho koledzhu - Collection of scientific works of Lutsk pedagogical college, 4, 72-80. Lutsk: Lutskyi pedahohichnyi koledzh [in Ukrainian].

11. Palko, T. V. (2015). Psykholohichni osoblyvosti 
rozvytku refleksii vchyteliv $\mathrm{v}$ umovakh pisliadyplomnoi pedahohichnoi osvity [Psychological peculiarities of the development of teachers' reflection in terms of postgraduate pedagogical education]. Extended abstract of candidate's thesis. Kyiv [in Ukrainian].

12. Petrovskiy, A. V., Yaroshevskiy, M. G. (Ed.). (1990). Psikhologiia. Slovar [Psychology. Dictionary]. Moscow: IPL [in Russian].

13. Rybalko, L. S. (2008). Akmeolohichni zasady profesiino-pedahohichnoi samorealizatsii maibutnoho vchytelia [Acmeological bases of future teacher's professional self-fulfillment]. Candidate's theis. Kharkiv [in Ukrainian].

14. Golovin, S. Yu. (1998). Slovar prakticheskogo psikhologa [Dictionary of a practical psychologist]. Minsk: Kharvest [in Russian].

15. Suvorova, N. G. (2000). Interaktivnoe obuchenie: novye podkhody [Interactive teaching: new approaches]. Uchitel-Teacher, 1, 25-27 [in Ukrainian].

16. Tur, R. Y. (2004). Pedahohichna refleksiia - osnova formuvannia tvorchoho samorozvytku osobystosti [Pedagogical reflection as a basis for the formation of personal self-development]. Upravlinnia shkoloiu School management, 13, 22-24. Kharkiv [in Ukrainian].

17. Ilicheva, L. F. (Ed.). (1983). Filosofskii entsiklopedicheskii slovar [Philosophic encyclopedic dictionary]. Moscow: Sov. Entsiklopediia [in Russian].

Наталія Геннадіївна Сенчина, Методист науково-методичного иентру післядипломної освіти вчителів іноземних мов, Одеський обласний інститут удосконалення вчителів, провулок Нахімова, 8, м. Одеса, Україна, аспірант кафедри теорії та методики дошкільної освіти, Південноукраӥнський національний педагогічний університет імені К. Д. Уиинського, вул. Старопортофранківська, 26, м. Одеса, Украӥна

\section{ПРОБЛЕМАТИКА РОЗВИТКУ ПЕДАГОГІЧНОЇ РЕФЛЕКСІЇ ВЧИТЕЛІВ ГУМАНІТАРНИХ СПЕЦАЛЬНОСТЕЙ НА СУЧАСНОМУ ЕТАПІ}

Модернізація сучасної шкільної освіти висуває підвищені вимоги до роботи вчителів, у тому числі й учителів гуманітарних спеціальностей, що зумовлює необхідність постійного саморозвитку, самовдосконалення задля творчої й активної самореалізації в професійній діяльності, досягнення професіоналізму. Неодмінною умовою професійного самовдосконалення вчителя гуманітарних дисциплін $є$ його розвинена здатність до рефлексії, що передбачає самопізнання, самоаналіз й самооцінку власної діяльності, самого себе як іiї суб’єкта, розуміння того, як інші сприймають його особистість. Особливе місце в розвитку рефлексії вчителів-практиків належить системі післядипломної педагогічної освіти, що за своїм призначенням орієнтована на їхнє професійне вдосконалення. Підтримка професійної кваліфікації вчителів, розвиток їхніх професійних якостей, у тому числі й педагогічної рефлексії, в системі післядипломної педагогічної освіти впливатиме на підвищення якості шкільної освіти, забезпечуючи формування цілісної, духовно багатої особистості школярів. Мета дослідження полягає в теоретичному розгляді проблематики розвитку педагогічної рефлексії вчителів гуманітарних спеціальностей в умовах модернізації сучасної шкільної освіти. Для досягнення поставленої мети використано загальнонаукові методи теоретичного рівня: аналіз наукової психологопедагогічної літератури, узагальнення одержаної інформації, а також методи емпіричного рівня: анкетування, діагностування, спостереження, бесіди тощо. У своєму теоретичному, концептуальному розумінні рефлексія є формою активного переосмислення людиною тих чи тих змістів індивідуальної свідомості, діяльності, спілкування, а в широкому практичному сенсі - це здатність людини до самоаналізу, осмислення й переосмислення своїх предметносоціальних відносин із довкіллям і є складовою частиною розвиненого інтелекту. У професійній діяльності вчителя важливою є його здатність до педагогічної рефлексії, щзо допомагає йому виробити індивідуальний стиль діяльності, дозволяє досягти адекватної самооцінки власної діяльності, прогнозувати й аналізувати ііі результати, спонукає до самовдосконалення. Педагогічна рефлексія розглядається як здатність учителя до самоспостереження, самопізнання, самоаналізу власної діяльності, вміння зіставляти оцінки особистісних особливостей довколишніми людьми із власним баченням себе, критично оцінювати власні досягнення в професійній діяльності, визначати шляхи професійноособистісного розвитку. Подано дані анкетування вчителів гуманітарних дисциплін щодо обізнаності із сутністю педагогічної рефлексії, результати діагностування рівнів сформованості рефлексивних умінь учителів гуманітарних спеціальностей. Одержані результати свідчать про необхідність вирішення проблематики розвитку педагогічної рефлексії учителів гуманітарних дисциплін у системі післядипломної освіти, чому сприятиме використання під час підвищення кваліфікації різноманітних ділових і рольових ігор дискусій, аналізу педагогічних ситуацій, спрямованих на вдосконалення рефлексивних умінь. Перспективою подальших досліджень $є$ розробка методики розвитку педагогічної рефлексії учителів гуманітарних дисциплін у системі післядипломної освіти.

Ключові слюва: рефлексія, педагогічна рефлексія, вчителі гуманітарних дисциплін, система післядипломної освіти.

Submitted on April, 27, 2017

Reviewed by Doctor of Pedagogy, prof. T. Osypova 